\title{
Prevalence of Stemphylium Blight Disease on Kharif Onion in Bihar, India
}

\author{
J. K. Tiwari ${ }^{1 *}$, Arun Kumar ${ }^{2}$, H. M. Singh ${ }^{1}$, Divya ${ }^{3}$ and T.S. Mishra ${ }^{4}$ \\ ${ }^{I}$ National Horticultural Research and Development Foundation, Patna (Bihar), India \\ ${ }^{2}$ Bihar Agricultural University, Sabour-Bhagalpur (Bihar), India \\ ${ }^{3}$ Sam Higginbottom University of Agriculture, Technology and Science, \\ Prayagraj (U.P.), India \\ ${ }^{4}$ KVK West Kameng, Dirang (Arunchal Pradesh), India \\ *Corresponding author
}

\section{A B S T R A C T}

Survey conducted during the year 2018 and 2019 at three stage of crop growth of onion in six districts of the Bihar revealed the prevalence of disease in all onion growing areas of the Bihar during the month of $2^{\text {nd }}$ fortnight of August, September and October, while during the month of prevalence of disease was recorded at only few locations with less intensity, while as rest of the locations were disease minimum incidence with overall

\section{Keywords}

Prevalence,

Disease, Onion, Incidence, Intensity

\section{Article Info}

Accepted:

28 April 2020

Available Online:

10 May 2020 incidence of $2.47,24.58$ and 39.07 and intensity of $0.99,6.02$ and $16.77 \%$, during the month of August, September and October, respectively. The disease was severe during 2019 with overall mean disease incidence of $2.76,25.34$ and 41.32 and intensity of 1.15 , 6.52 and $17.45 \%$ in comparison to 2018 with overall incidence of $2.17,23.82$ and 37.78 and intensity of 0.83, 5.52 and $16.09 \%$, during the month of August, September and October, respectively. Perusal of the pooled data of two years revealed that the disease incidence and intensity in surveyed districts varied from 31.50 to 57.97 and 14.19 to 18.26 $\%$, respectively with highest incidence and intensity recorded in Patna and lowest in Samastipur of the 6 districts surveyed, highest disease incidence $(61.99 \%)$ was recorded at Barh Patna followed by Fatuwa (60.16\%), Patna city (55.16\%), Danapur (54.56\%), Bhojpur Kadid (50.86 \%), Dumraon (49.39\%), Turiganj (47.70\%) and Raghunathpur (42.56\%) Whereas highest disease intensity $(22.89 \%)$ was recorded at Barh Patna followed by Bhojpur Kadid Baxur (22.02 \%), Begusarai (21.55 \%), Harnaut Nalanda (21.07 \%), Desari Vaishali (20.60 \%), Dumraon Baxur (20.48 \%), Fatuwa Patna (20.06 \%) and least incidence $(29.04 \%)$ in Bihar Sharif was recorded and least intensity $(11.02 \%)$ in Dalsinghsarai Samastipur was recorded.

\section{Introduction}

Onion is the one of the most important commercial vegetable crops grown in India. It is grown in north to south as well as whole India. The most important onion-growing states are Maharashtra, Madhya Pradesh, Karnataka, Gujarat, Bihar, Andhra Pradesh, Rajasthan, Haryana, Punjab and others (DACFW 2018). In 2017-18 the area under onion in Bihar was about 53772.95 ha with production was 1267182.46 MT. Several 
factors have been identified for the low productivity of onion in India as well as in Bihar. It is the member of the family Alliaceae. It is also used as popular vegetable in India and very common, favourite spice in India. Onion has manifold uses as spices, vegetables, salad dressing etc. Onion are used as cooked in various ways in all curries, fried, boiled, baked, used in soup making, in pickles and for other purposes. It is also used as condiments for flavouring a number of food and medicines (Ureba et al., 1999). Onion is one of the vegetables which are exported. Onion suffers from many diseases caused by fungi, bacteria, viruses, nematodes and abiotic factors (Meah and Khan, 1987). Among the fungal disease stemphylium blight (Stemphylium vesicarium) is the most serious and devastating disease of onion limiting the quality and quantity of both bulb and seed (Daljeet et al., 1992).

The disease is caused by Stemphylium vesicarium (Wallroth). This foliar disease is serious in north western India, particularly in seed crop. The infection occurs on radial leaves of transplanted seedlings at 3-4 leaf stage and flower stalk during April and May. The disease is characterized by appearance of small yellow to orange streaks which soon developed into elongated, spindle shaped to ovate elongate diffusive spots surrounded by characteristics pinkish margin. It can cause severe damage, especially to the onion seed crop and losses of about $80-85 \%$ on the crop by affecting leaves and seed stalk. This disease is widespread particularly in rainy season or high moisture conditions. Thus, survey and surveillance from the basis is useful for any successful plant protection strategy. Successful plant protection depends upon early detection of the disease severity followed by timely adoption and application of preventive measures (Srivastava et al., 2005). However, systematic survey on the distribution and severity in 6 districts of Bihar is lacking. There is need to undertake systemic survey to identify hot spots for these diseases in all districts. Keeping all these aspects in view, the present investigation was undertaken to know the disease severity in major 6 onion growing district.

\section{Materials and Methods}

The present investigation was conducted during the month of August, September and October on kharif season onion in two years i.e. 2018-2019 in the 24 villages of six districts in Bihar. The materials and methods which were adopted to achieve the set goals are described as follows:

\section{Status of the disease}

To ascertain the status of disease, extensive survey of onion growing areas of six districts viz., Patna, Nalanda, Vaishali, Baxur, Begusarai and Samastipur of Bihar was conducted during the second fortnight of August, September and October of cropping season 2018 and 2019. Four representative villages from each district and three random onion fields were selected from each village. Ten plants from each site were observed for recording per cent disease incidence and intensity.

The per cent disease incidence shall be calculated as per the formula given below: Five categories were made on the basis of percent leaf area diseased (Plate) as per the following key. The details of scales are as shown below.

No disease symptoms.

A few spots towards tip covering 10 percent leaf area.

Several dark purplish brown patch covering up to 20 percent leaf area.

Several patches with paler outer zone covering up to 40 percent leaf area. 
Leaf streaks covering up to 75 percent leaf area or breaking of the leaves from center.

Complete drying of the leaves or breaking of the leaves from center.

Percent Disease Incidence (PDI) shall be worked out by using the following formula:

Further, disease incidence percent (DI \%) and disease intensity was worked out by using following formula proposed by Wheeler (1969).

\section{(1) $\mathrm{PDI}=$}

Total number of plant infected/ Diseased

Total no. of plant observed

(2) Disease Intensity

Total sum of all ratings $\times 100$

Total no. of leaves observed x Maximum number of rating

\section{Results and Discussion}

\section{Status of the disease}

The disease survey was conducted in six districts of Bihar namely, Patna, Nalanda, Vaishali, Baxur, Begusarai and Samastipur during two consecutive years i.e. 2018 and 2019. Incidence and intensity was recorded at three stages of survey each year during the second fortnight of August, September and October and the data is presented in Table 1 and 2.

\section{Disease incidence}

The data reveals (Table 1) that stemphylium blight of onion was prevalent in all the locations surveyed with varying degree of incidence, which was minimum in first but maximum in last (third) stage of survey. Disease incidence in the third stage of survey ranged between $28.07 \%$ and $60.32 \%$ and 29.65 and $63.65 \%$ during 2018 and 2019, respectively. During the year 2018, highest disease incidence of $6.14 \%$ at first stage of survey ( $2^{\text {nd }}$ fortnight of August) was recorded at Barh Patna followed by Fatuwa Patna (4.17 $\%)$, Bhojpur Kadid Baxur (3.95\%) and minimum of $0.75 \%$ was recorded at Dalsinghsarai Samastipur while as rest of locations were disease less. During the second stage of survey ( $2^{\text {nd }}$ fortnight of September), the highest disease incidence of $29.53 \%$ was recorded at Barh Patna, followed by Fatuwa Patna (27.72 \%), Patna city (26.25\%), Raghunathpur Buxar (26.06 \%), Dumraon Buxar/Begusarai (26.05\%) and Bibhutipur Samastipur (25.62\%), which had increased to $60.32 \%$ in Barh Patna, 58.57 \% Fatuwa Patna , $54.05 \%$ Patnacity, $51.02 \%$ Danapur Patna, $49.67 \%$ Bhojpur Kadid Buxar, $47.14 \%$ Dumraon Buxar at third stage of survey. Other localities, which followed in decreasing order of disease incidence during the second and third stages of survey during 2018. Minimum disease incidence of $19.15 \%$ and $28.42 \%$ at second and third stages, respectively during 2018 was recorded at Bihar Sharif, Nalanda district. Whereas least disease incidence of $28.07 \%$ at third stages during 2018 was recorded at Hajipur, Vaishali district. The data further reveals that disease incidence during 2019 varied between different locations in the same way as in 2018. During the year 2019, highest disease incidence of $5.45 \%$ at first stage of survey $\left(2^{\text {nd }}\right.$ fortnight of August) was recorded at Bhojpur Kadid Buxar followed by Barh Patna (5.27 \%), Dumraon Buxar (5.26 \% ), Turiganj Buxar (4.85 \%), Raghunathpur Buxar (4.64 $\%$ ) and minimum of $1.32 \%$ was recorded at Hajipur Vaishali while as rest of locations were disease less. During the second stage of survey $\left(2^{\text {nd }}\right.$ fortnight of September), the 
highest disease incidence of $33.15 \%$ was recorded at Barh Patna, followed by Bhojpur Kadid Buxar (29.56\%), Fatuwa Patna (28.75 $\%)$, Danapur.

Patna (28.56 \%), Patnacity (28.17\%) and Dumraon Buxar (27.24 \%) and lowest in Hajipur Vaishali (20.89 \%), which had increased to $63.65 \%$ in Barh Patna, $61.75 \%$ Fatuwa Patna, 58.15\% Danapur Patna, 56.26 \% Patnacity, $52.04 \%$ Bhojpur Kadid, 51.64 $\%$ Dumraon , $49.75 \%$ in Turiganj Buxar and lowest $29.65 \%$ in B. Sharif Nalanda district at third stage of survey. Other localities, which followed in decreasing order of disease incidence during the second and third stages of survey during 2019. Minimum disease incidence of $20.89 \%$ and $29.65 \%$ at second and third stages, respectively during 2019 was recorded at Hajipur Vaishali and Bihar Sharif, Nalanda district (Jakhar et al., 1994).

The pooled data of 2018-19 revealed that highest disease incidence of $5.71 \%$ at first stage ( $2^{\text {nd }}$ fortnight of August), of survey was recorded at Barh Patna, followed by Bhojpur Kadid Buxar (4.70 \%), Dumraon Buxar (4.26 $\%$ ), Fatuwa Patna (4.22 \%), Turiganj Buxar $(4.00 \%)$ and minimum at Dalsinghsarai (1.16 $\%$ ) of district Samastipur while as rest of locations were disease less incidence during first stage of survey. During the second stage of survey ( $2^{\text {nd }}$ fortnight of September), the highest disease incidence of $31.34 \%$ was recorded at Barh Patna followed by Bhojpur Kadid Buxar (28.86 \%), Fatuwa Patna (28.24 $\%$ ), Patnacity (27.21\%), Dumraon Buxar (26.65 \%), Begusarai (26.57\%), Maithani Begusarai ( $21.40 \%$ ), Hajipur Vaishali (20.42 $\%$ and lowest in Bihar Sharif Nalanda ( 20.09 $\%)$ ), which had increased $3^{\text {rd }}$ stage of survey ( $2^{\text {nd }}$ fortnight of October) to Barh Patna $(61.99 \%)$ followed by Fatuwa Patna (60.16 $\%)$, Patnacity $(55.16 \%)$ Danapur Patna $(54.56 \%)$. Whereas lowest disease incidence was recorded in Bihar Sharif (29.04\%) of Nalanda district (Fig. 1).

\section{Disease intensity}

The data presented in Table 2 revealed that intensity of stemphylium blight of onion varied between locations surveyed and was minimum at each locality at the time of first stage of survey but maximum at third stage of survey ranged between $10.78 \%$ to $21.37 \%$, and $11.26 \%$ to $24.45 \%$ during 2018 and 2019, respectively. During the year 2018, highest disease intensity of $1.85 \%$ at first stage of survey ( $2^{\text {nd }}$ fortnight of August) was recorded at Barh Patna followed by Fatuwa Patna (1.27 \%), Bhojpur Kadid Buxar (1.14\%), Begusarai (1.07\%), Patnacity (1.06 $\%)$ and minimum of $(0.02 \%)$ was recorded at Dalsingsarai Samastipur while as rest of locations were disease less. During the second stage of survey ( $2{ }^{\text {nd }}$ fortnight of September), the highest disease intensity of $8.76 \%$ was recorded at Barh Patna, followed by Fatuwa Patna (8.08 \%), Bhojpur Kadid Buxar (7.45 $\%)$, Dumraon Buxar (7.12 \%), Patna city $(7.10 \%)$ and Dalsinghsarai Samastipur (1.34 $\%$ ), which had increased to $21.37 \%$ at Barh Patna followed by Bhojpur Kadid Buxar (21.25\%), Begusarai (21.08\%), Harnaut Nalanda (20.34 \%), Desari Vaishali $(20.05 \%)$ and least in Dalsinghsarai Samastipur (10.78 $\%$ )at third stage of survey. Other localities, which followed in decreasing order of disease incidence during the second and third stages of survey during 2018. During the year 2019, highest disease intensity of $2.05 \%$ at first stage of survey ( $2^{\text {nd }}$ fortnight of August) was recorded at Bhojpur Kadid Buxar, followed by Barh Patna (1.97 \%), Dumraon Buxar (1.85\%), Fatuwa Patna (1.82 \%), Patna city (1.53\%), Turiganj Buxar (1.32 \%) and minimum of $(0.45 \%)$ was recorded at Dalsinghsarai Samastipur while as rest of locations were observe less disease. During the second stage of survey ( $2{ }^{\text {nd }}$ fortnight of September), the highest disease intensity of $9.08 \%$ was recorded at Barh Patna, followed by Bhojpur Buxar (9.02 \%), Fatuwa Patna $(8.84 \%)$, Begusarai (8.75 \%), Dumraon 
Buxar $(8.24 \%)$ and lowest at Dalsinghsarai Samastipur ( $3.15 \%$ ), respectively which had increased to $24.45 \%$ at Barh Patna followed by Bhojpur Kadid Buxar (22.78 \%), Begusarai $(22.02 \%)$, Fatuwa Patna $(21.84$
\%), Harnaut Nalanda (21.80 \%), Dumraon Buxar $(21.21 \%)$ and least at Dalsinghsarai Samastipur (11.26\%) at third stage of survey (Fig. 2 and 3).

Table.1 Incidence of stem phylum blight of onion ( $S$. vesicarium) at various locations of Bihar during 2018-19

\begin{tabular}{|c|c|c|c|c|c|c|c|c|c|c|c|}
\hline \multirow{3}{*}{$\begin{array}{l}\text { S. } \\
\text { N. }\end{array}$} & \multirow[t]{3}{*}{ District } & \multirow[t]{3}{*}{ Locations } & \multicolumn{9}{|c|}{ Disease incidence \% } \\
\hline & & & \multicolumn{3}{|c|}{2018} & \multicolumn{3}{|c|}{2019} & \multicolumn{3}{|c|}{ Pooled } \\
\hline & & & August & $\begin{array}{l}\text { Septem } \\
\text { ber }\end{array}$ & $\begin{array}{c}\text { Octob } \\
\text { er }\end{array}$ & $\begin{array}{l}\text { Augu } \\
\text { st }\end{array}$ & $\begin{array}{c}\text { Septem } \\
\text { ber }\end{array}$ & $\begin{array}{c}\text { Octob } \\
\text { er }\end{array}$ & $\begin{array}{c}\text { Augu } \\
\text { st }\end{array}$ & $\begin{array}{l}\text { Septe } \\
\text { mber }\end{array}$ & $\begin{array}{c}\text { Octobe } \\
r\end{array}$ \\
\hline \multirow[t]{5}{*}{1} & \multirow{5}{*}{ Samastipur } & Kalyanpur & 1.12 & 22.26 & 31.32 & 1.86 & 23.62 & 32.45 & 1.49 & 22.94 & 31.89 \\
\hline & & Dalsinghsarai & 0.75 & 20.95 & 29.75 & 1.56 & 22.06 & 31.04 & 1.16 & 21.51 & 30.40 \\
\hline & & Bibhutipur & 1.62 & 25.62 & 32.03 & 2.05 & 26.15 & 34.06 & 1.84 & 25.89 & 33.05 \\
\hline & & Tajpur & 1.05 & 21.26 & 30.26 & 1.74 & 22.35 & 31.08 & 1.40 & 21.81 & 30.67 \\
\hline & & Mean & 1.14 & 22.52 & 30.84 & 1.80 & 23.55 & 32.16 & 1.47 & 23.04 & 31.50 \\
\hline \multirow[t]{5}{*}{2} & \multirow[t]{5}{*}{ Nalanda } & Chandi & 2.15 & 23.26 & 32.07 & 2.36 & 24.45 & 34.76 & 2.26 & 23.86 & 33.42 \\
\hline & & Noorsarai & 2.06 & 21.84 & 33.12 & 2.43 & 23.74 & 33.65 & 2.25 & 22.79 & 33.39 \\
\hline & & Bihar Sarif & 1.75 & 19.15 & 28.42 & 2.25 & 21.02 & 29.65 & 2.00 & 20.09 & 29.04 \\
\hline & & Harnaut & 2.25 & 24.07 & 33.35 & 2.58 & 25.75 & 35.02 & 2.42 & 24.91 & 34.19 \\
\hline & & Mean & 2.05 & 22.08 & 31.74 & 2.41 & 23.74 & 33.27 & 2.23 & 22.91 & 32.56 \\
\hline \multirow[t]{5}{*}{3} & \multirow[t]{5}{*}{ Baxur } & Bhojpur Kadid & 3.95 & 28.15 & 49.67 & 5.45 & 29.56 & 52.04 & 4.70 & 28.86 & 50.86 \\
\hline & & Turiganj & 3.15 & 25.24 & 45.64 & 4.85 & 25.85 & 49.75 & 4.00 & 25.56 & 47.70 \\
\hline & & Dumraon & 3.25 & 26.05 & 47.14 & 5.26 & 27.24 & 51.64 & 4.26 & 26.65 & 49.39 \\
\hline & & Raghunathpur & 2.06 & 25.06 & 39.85 & 4.64 & 25.76 & 45.26 & 3.35 & 25.41 & 42.56 \\
\hline & & Mean & 3.10 & 26.13 & 45.56 & 5.05 & 27.10 & 49.67 & 4.08 & 26.62 & 47.63 \\
\hline \multirow[t]{5}{*}{4} & \multirow[t]{5}{*}{ Patna } & Barh & 6.14 & 29.53 & 60.32 & 5.27 & 33.15 & 63.65 & 5.71 & 31.34 & 61.99 \\
\hline & & Danapur & 1.86 & 24.41 & 51.02 & 2.42 & 28.56 & 58.15 & 2.14 & 26.49 & 54.56 \\
\hline & & Fatuwa & 4.17 & 27.72 & 58.57 & 4.26 & 28.75 & 61.75 & 4.22 & 28.24 & 60.16 \\
\hline & & Patna city & 2.27 & 26.25 & 54.05 & 3.25 & 28.17 & 56.26 & 2.76 & 27.21 & 55.16 \\
\hline & & Mean & 3.61 & 26.98 & 55.99 & 3.80 & 29.66 & 59.95 & 3.71 & 28.32 & 57.97 \\
\hline \multirow[t]{5}{*}{5} & \multirow[t]{5}{*}{ Vaishali } & Jandaha & 1.27 & 21.74 & 29.88 & 1.35 & 22.95 & 32.78 & 1.31 & 22.35 & 31.33 \\
\hline & & Desari & 1.68 & 23.04 & 34.06 & 1.94 & 25.21 & 36.12 & 1.81 & 24.13 & 35.09 \\
\hline & & Mahuva & 1.32 & 22.63 & 31.95 & 1.54 & 23.02 & 33.04 & 1.43 & 22.83 & 32.49 \\
\hline & & Hajipur & 1.14 & 19.95 & 28.07 & 1.32 & 20.89 & 31.06 & 1.23 & 20.42 & 29.57 \\
\hline & & Mean & 1.35 & 21.84 & 30.99 & 1.54 & 23.02 & 33.25 & 1.45 & 22.43 & 32.12 \\
\hline \multirow[t]{6}{*}{6} & \multirow[t]{6}{*}{ Begusarai } & Jagdishpur & 1.65 & 22.78 & 30.65 & 1.82 & 24.06 & 32.54 & 1.74 & 23.42 & 31.60 \\
\hline & & Begusarai & 2.05 & 26.05 & 35.34 & 2.31 & 27.08 & 37.08 & 2.18 & 26.57 & 36.21 \\
\hline & & Rashidpur & 1.86 & 24.36 & 31.28 & 2.01 & 26.11 & 33.01 & 1.94 & 25.24 & 32.15 \\
\hline & & Matihani & 1.54 & 20.19 & 29.08 & 1.67 & 22.61 & 31.89 & 1.61 & 21.40 & 30.49 \\
\hline & & Mean & 1.78 & 23.35 & 31.56 & 1.95 & 24.97 & 39.63 & 1.87 & 24.16 & 32.61 \\
\hline & & Overall Mean & 2.17 & 23.82 & 37.78 & 2.76 & 25.34 & 41.32 & 2.47 & 24.58 & 39.07 \\
\hline
\end{tabular}


Table.2 Intensity of Stem phylum blight of Onion (S. vesicarium) at various locations of Bihar during 2018-19

\begin{tabular}{|c|c|c|c|c|c|c|c|c|c|c|c|}
\hline \multirow[t]{3}{*}{ S. No. } & \multirow[t]{3}{*}{ District } & \multirow[t]{3}{*}{ Locations } & \multicolumn{9}{|c|}{ Disease intensity \% } \\
\hline & & & \multicolumn{3}{|c|}{2018} & \multicolumn{3}{|c|}{2019} & \multicolumn{3}{|c|}{ Pooled } \\
\hline & & & August & September & October & August & September & October & August & September & October \\
\hline \multirow[t]{5}{*}{1} & \multirow[t]{5}{*}{ Samastipur-6 } & Kalyanpur-2 & 0.53 & 3.65 & 14.81 & 0.95 & 4.32 & 16.35 & 0.74 & 3.99 & 15.58 \\
\hline & & Dalsinghsarai-4 & 0.02 & 1.34 & 10.78 & 0.45 & 3.15 & 11.26 & 0.24 & 2.25 & 11.02 \\
\hline & & Tajpur-3 & 0.45 & 2.26 & 12.02 & 0.89 & 3.45 & 14.05 & 0.67 & 2.86 & 13.04 \\
\hline & & Bibhutipur-1 & 0.78 & 4.24 & 16.15 & 1.02 & 5.04 & 18.06 & 0.90 & 4.64 & 17.11 \\
\hline & & Mean & 0.45 & 2.87 & 13.44 & 0.83 & 3.99 & 14.93 & 0.64 & 3.44 & 14.19 \\
\hline \multirow[t]{5}{*}{2} & \multirow[t]{5}{*}{ Nalanda*4 } & Chandi-2 & 0.94 & 5.76 & 18.06 & 1.09 & 6.35 & 18.75 & 1.02 & 6.06 & 18.41 \\
\hline & & Noorsarai-3 & 0.68 & 5.65 & 15.04 & 0.98 & 6.06 & 16.68 & 0.83 & 5.86 & 15.86 \\
\hline & & Bihar Sarif & 0.42 & 4.04 & 12.25 & 0.64 & 4.84 & 12.98 & 0.53 & 4.44 & 12.62 \\
\hline & & Harnaut-1 & 1.05 & 5.85 & 20.34 & 1.22 & 7.63 & 21.80 & 1.14 & 6.74 & 21.07 \\
\hline & & Mean & 0.77 & 5.33 & 16.42 & 0.98 & 6.22 & 17.55 & 0.88 & 5.78 & 16.99 \\
\hline \multirow[t]{5}{*}{3} & \multirow[t]{5}{*}{ Baxur-2 } & Bhojpur Kadid-1 & 1.14 & 7.45 & 21.25 & 2.05 & 9.02 & 22.78 & 1.60 & 8.24 & 22.02 \\
\hline & & Turiganj-3 & 0.98 & 6.10 & 16.08 & 1.32 & 7.09 & 16.95 & 1.15 & 6.59 & 16.52 \\
\hline & & Dumroan-2 & 1.03 & 7.12 & 19.75 & 1.85 & 8.24 & 21.21 & 1.44 & 7.68 & 20.48 \\
\hline & & Raghunathpur & 0.75 & 5.02 & 13.26 & 1.04 & 6.34 & 14.78 & 0.90 & 5.68 & 14.02 \\
\hline & & Mean & 0.98 & 6.42 & 17.59 & 1.57 & 7.67 & 18.93 & 1.27 & 7.05 & 18.26 \\
\hline \multirow[t]{5}{*}{4} & \multirow[t]{5}{*}{ Patna-1 } & Barh-1 & 1.85 & 8.76 & 21.37 & 1.97 & 9.08 & 24.45 & 1.91 & 8.92 & 22.89 \\
\hline & & Danapur-4 & 0.65 & 6.65 & 11.03 & 1.15 & 7.15 & 14.06 & 0.90 & 6.90 & 12.55 \\
\hline & & Fatwa-2 & 1.27 & 8.08 & 18.27 & 1.82 & 8.84 & 21.84 & 1.55 & 8.46 & 20.06 \\
\hline & & Patna city-3 & 1.06 & 7.10 & $14 . .25$ & 1.53 & 8.07 & 16.02 & 1.30 & 7.59 & 15.14 \\
\hline & & Mean & 1.21 & 7.65 & 16.22 & 1.62 & 8.29 & 19.09 & 1.42 & 7.97 & 17.66 \\
\hline \multirow[t]{5}{*}{5} & \multirow[t]{5}{*}{ Vaishali*5 } & Jandaha-3 & 0.52 & 4.02 & 14.12 & 0.64 & 4.98 & 15.08 & 0.58 & 4.50 & 14.60 \\
\hline & & Desari-1 & 1.02 & 5.09 & 20.05 & 1.12 & 6.67 & 21.14 & 1.07 & 5.88 & 20.60 \\
\hline & & Mahua-2 & 0.89 & 4.95 & 17.13 & 1.04 & 6.14 & 17.85 & 0.97 & 5.55 & 17.49 \\
\hline & & Hajipur-4 & 0.37 & 3.51 & 11.95 & 0.43 & 3.99 & 12.38 & 0.40 & 3.75 & 12.17 \\
\hline & & Mean & 0.70 & 4.39 & 15.81 & 0.81 & 5.45 & 16.61 & 0.76 & 4.92 & 16.22 \\
\hline \multirow[t]{6}{*}{6} & \multirow[t]{5}{*}{ Begusarai-3 } & Jagdishpur-3 & 0.56 & 6.04 & 15.42 & 0.79 & 6.87 & 15.81 & 0.68 & 6.46 & 15.62 \\
\hline & & Matihani & 0.75 & 5.68 & 12.85 & 1.08 & 6.13 & 13.09 & 0.92 & 5.91 & 12.97 \\
\hline & & Rashidpur-2 & 0.98 & 6.65 & 18.84 & 1.14 & 8.12 & 19.31 & 1.06 & 7.43 & 19.08 \\
\hline & & Begusarai-1 & 1.07 & 7.34 & 21.08 & 1.26 & 8.75 & 22.02 & 1.17 & 8.05 & 21.55 \\
\hline & & Mean & 0.84 & 6.43 & 17.05 & 1.07 & 7.47 & 17.56 & 0.96 & 6.96 & 17.31 \\
\hline & & Overall Mean & 0.83 & 5.52 & 16.09 & 1.15 & 6.52 & 17.45 & 0.99 & 6.02 & 16.77 \\
\hline
\end{tabular}




\section{Fig. 1: Disease Incidence \%}
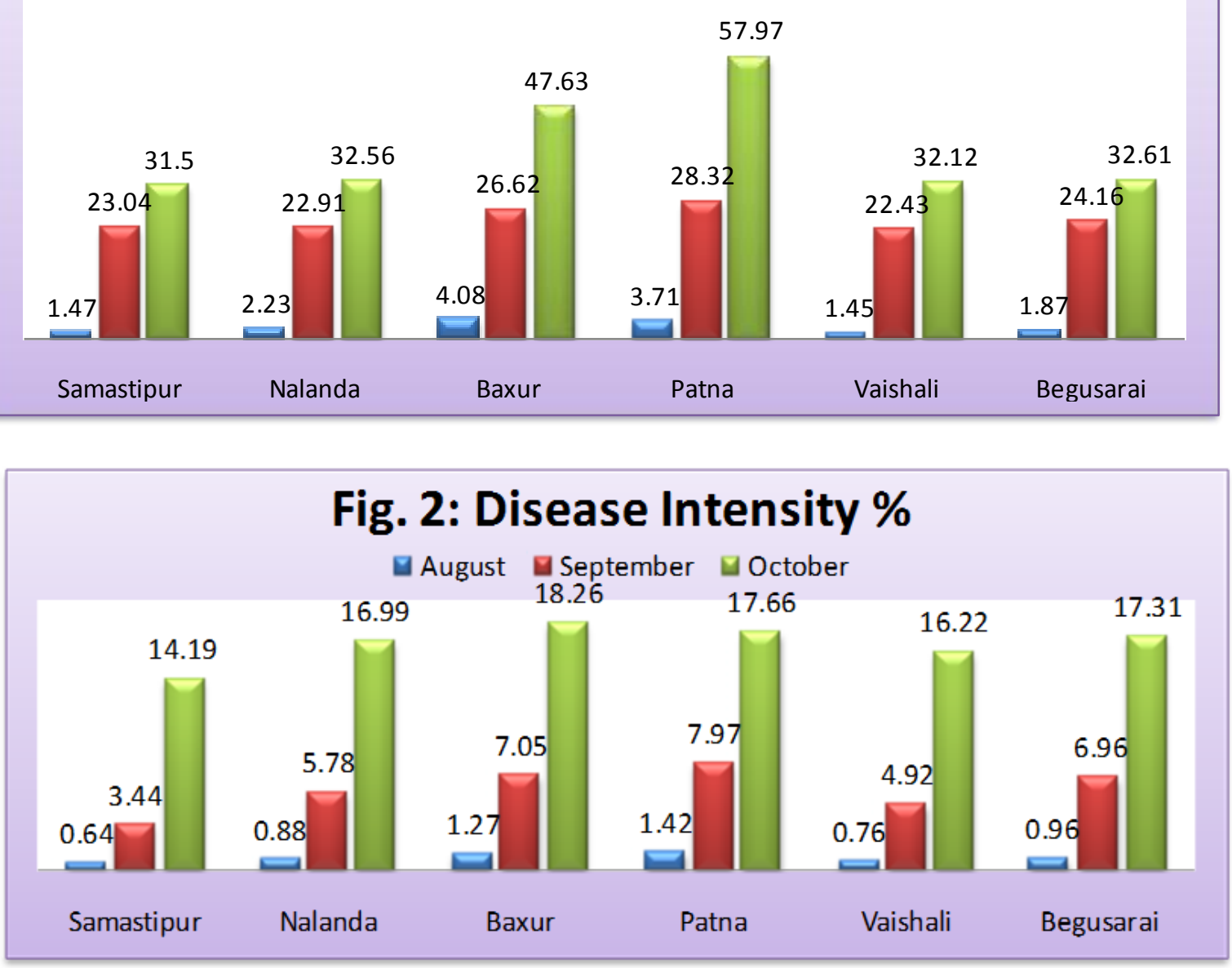

Figure.3 Stem phylum blight of onion plants
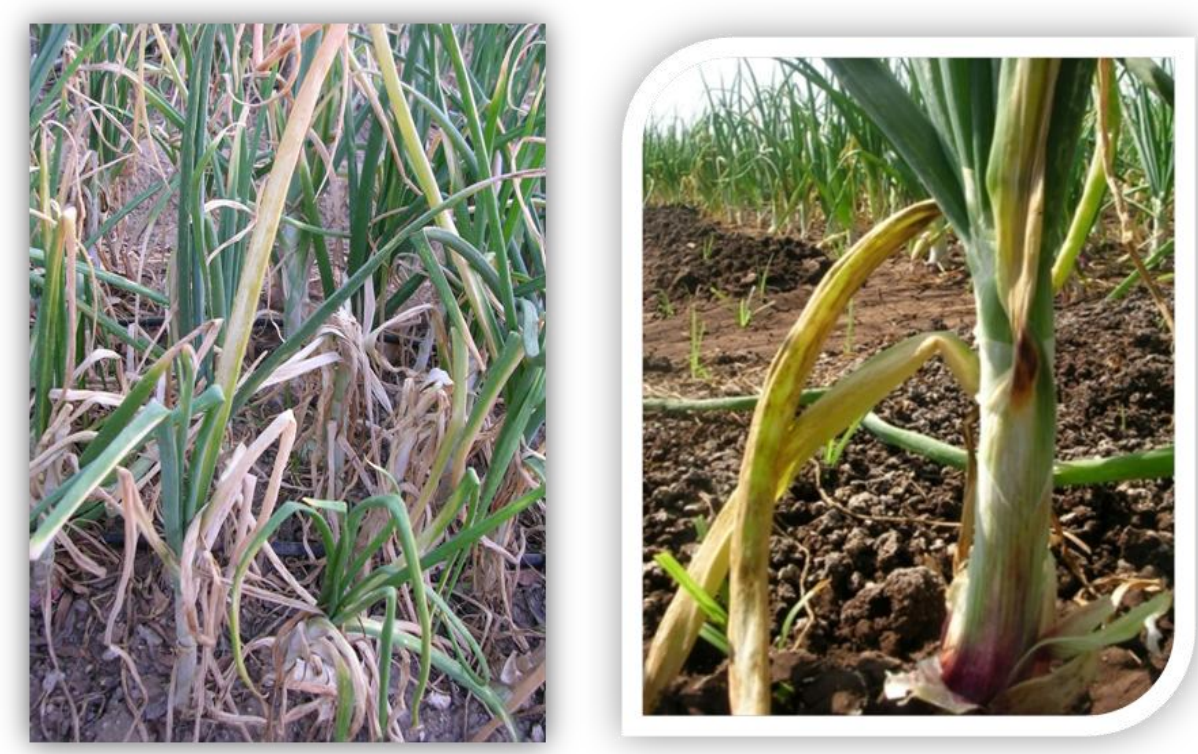
The pooled data of 2018-19 revealed that highest disease intensity of $1.91 \%$ at first stage of survey was recorded at Barh Patna followed by Bhojpur Buxar (1.60 \%), Fatuwa Patna (1.55 \%), Dumraon Buxar (1.44 \%), Patna city (1.30\%), Begusarai (1.17\%) and minimum at Daisinghsarai $(0.24 \%)$ of district Samastipur while as rest of locations were less disease during first stage of survey.

During the second stage of survey ( $2^{\text {nd }}$ fortnight of September), the highest disease intensity of $8.92 \%$ was recorded at Barh district of Patna, followed by Fatuwa Patna (8.46 \%), Bhojpur Kadid Buxar (8.24 $\%$ ), Begusarai (8.05\%), Dumraon Buxar (7.68 \%) and lowest at Dalsinghsarai Samastipur (2.25\%), respectively . which had increased to $22.89 \%$ at Barh Patna followed by Bhojpur Kadid Buxar (22.02\%), Begusarai (21.55\%), Harnaut Nalanda (21.07 $\%)$, Desari Vaishali $(20.60 \%)$ and least in Dalsinghsarai Samastipur $(11.02 \%)$ at third stage of survey. Other localities, which followed in decreasing order of disease incidence during the third stages of survey during 2018-19 pooled data. Higher disease incidence and intensity in various districts and sites could be attributed to higher plant density, besides non disposal of diseased leaves, lack of improved practices of onion cultivation which serve as a source for buildup of primary inoculum. Overall, variation in disease severity may be because of the variation in various factors like, altitude, climate and management practices. The variations in incidence and severity of stemphylium blight of onion in various locations have previously been reported by (Mishra et al., 2013). Koppad et al., (2017) reported that stemphylium blight severity ranged from 21.24 to 54.35 per cent in carried out from onion growing districts viz., Dharwad, Gadag, Haveri, Uttar Kannada and Belagavi of Karnataka during kharif 2014-15.

\section{References}

Bisht, I. S. and Thomas, T. A.1992. Field screening of garlic germplasm against purple blotch and stemphylium blight. Indian Phytopathol. 45: 244.

Daljeet, S., Dhiman, J. S., Sidhu, A. S. and Hari Singh. 1992. Current status of onions in India. Strategies for distance resistance breeding for sustained production. Onion News letters for the Tropics4: 43-44.

DACFW. 2018. Department of Agriculture Cooperation and Farmers Welfare. Area and Production of Horticulture Crops - All India 2017-18. http://agricoop.nic.in/sites/default/ files/2017-18-\%28Final\%29_updt.pdf.

Gupta, R. P., Srivastava, K. J., Pandey, U. B. and Midmore, D. J. 1994. Diseases and insect pests of onion in India. International Symposium on Alliums for the Tropics. Acta Horti., 358: 265269.

Hassan, M. H. A. and Hussein, M. A. M. 2007. New Disease Report. Plant Pathology Department, Faculty of Agriculture, Assiut University, Egypt.

Jakhar, S. S., Duhan, J. C. and Suhag, L. S. 1994. Prevalence and incidence of Stemphylium blight of onion and its management through cultural practices. Crop Res. (Hissar). 8 (3): 562-564.

Mishra, R.K., Prasad, K., Pandey, S. and Gupta, R P. 2013. Evaluation of Garlic Accessions for Growth, Yield, Quality and Resistance to Stemphylium Blight Disease in Northern India. Vegetos. 26(2): 291-296

Meah, B. and Khan, A. A. 1987. Checklist of vegetables and fruit diseases in Bangladesh. Department of Plant Pathology, Bangladesh Agriculture University Mymensingh, pp. 22.

Srivastava, K. J., Tiwari, B. K., Sharma, R. C. 
and Chauhan, K. P. S. 2005. Evaluation of different advanced lines against Stemphylium blight, purple blotch and thrips insect pests of garlic. News letter NHRDF. 25 (1): 10-12. Int.J.Curr.Microbiol.App.Sci (2019) 8(4): 1875-1880 1880

Shilpa R. Koppad, S. R., Babaleshwar, S.B., Dharmatti, P. R and Kulkarni, S. 2017. Survey on prevalence and symptomatology of major diseases of onion (Allium cepa L.) in northern parts of Karnataka, India. Int.J.Curr. Microbiol.App.Sci 6(9): 2603-2607 -

Ureba, B.M.J., Prados-Ligero, A.M. and Melero-Vara, J.M. 1999. Aetiology of leaf spot of garlic and onion caused by Stemphylium vesicarium in Spain. Plant Pathology. 48:139-145.

\section{How to cite this article:}

Tiwari, J. K., Arun Kumar, H.M. Singh, Divya and Mishra, T.S. 2020. Prevalence of Stemphylium Blight Disease on Kharif Onion in Bihar. Int.J.Curr.Microbiol.App.Sci. 9(05): 3390-3398. doi: https://doi.org/10.20546/ijcmas.2020.905.403 